\title{
A nineteenth-century specimen of Simias concolor and an early twentieth-century specimen of Allenopithecus nigroviridis in the Finnish Museum of Natural History, Helsinki
}

\section{Pihlstrom, Henry}

2018-04

Pihlstrom , H \& Lankinen , T 2018 , ' A nineteenth-century specimen of Simias concolor and an early twentieth-century specimen of Allenopithecus nigroviridis in the Finnish Museum of Natural History, Helsinki ' , Archives of Natural History , vol. 45 , no. 1 , pp. 155-158 . https://doi.org/10.3366/anh.201

http://hdl.handle.net/10138/322137

https://doi.org/10.3366/anh.2018.0492

acceptedVersion

Downloaded from Helda, University of Helsinki institutional repository.

This is an electronic reprint of the original article.

This reprint may differ from the original in pagination and typographic detail.

Please cite the original version. 


\section{A nineteenth-century specimen of Simias concolor and an early twentieth-century specimen of Allenopithecus nigroviridis in the Finnish Museum of Natural History, Helsinki}

During a survey of the collections of the Finnish Museum of Natural History (FMNH) in Helsinki, Finland, in 2016, two old, previously misidentified primate specimens were encountered. The circumstances surrounding their additions to the collections of the FMNH are of historical interest.

The first specimen, which has the collection number UN 2619, consists of a nearly complete skeleton of a medium-sized monkey, mounted in a crouching position (Figure 1). The greatest length of the skull is $97.9 \mathrm{~mm}$ and the zygomatic width is $72.3 \mathrm{~mm}$. Dental wear and limb bone ossification suggest that the individual is an adult, and the relatively small canine teeth suggest that it is a female. The tail is incomplete; only seven caudal vertebrae are preserved. However, the two most distal of these preserved vertebrae are relatively long, and their transverse processes, neural arches, and ventral arches are reduced. Their morphology therefore suggests that they are situated near the actual end of the tail, and that the length of the complete tail would not have extended beyond at most a few additional vertebrae. Thus, the animal was short-tailed in life.



Figure 1. UN 2619; lateral view. (Photograph by Henry Pihlström, 6 February 2017; C Finnish Museum of Natural History, Helsinki.)

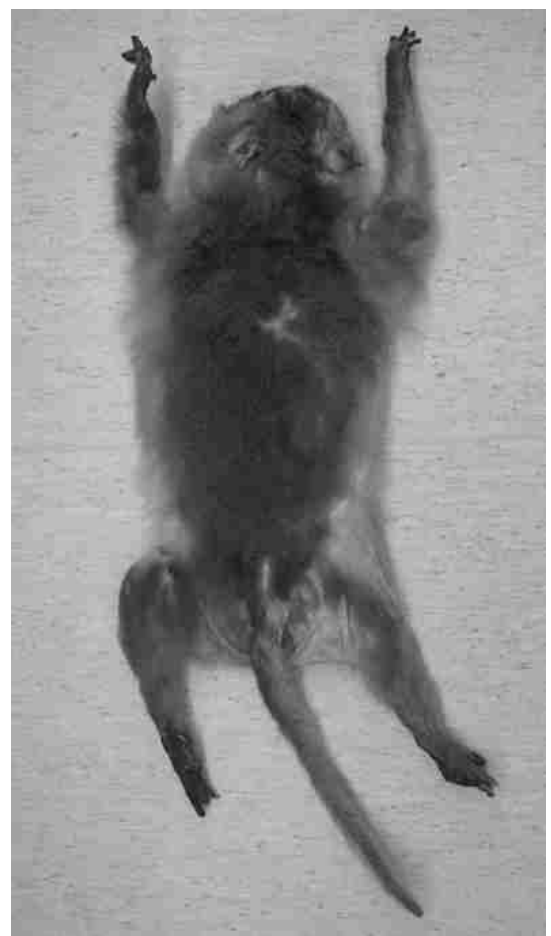

Figure 2. UN 1648; dorsal view. (Photograph by Henry Pihlström, 2 November 2016; (C) Finnish Museum of Natural History, Helsinki.) 
According to the original label, the specimen was prepared in 1861. Its locality is given as "Sumatra", with the additional note that it arrived in Helsinki via the Leyden (Leiden) Museum in the Netherlands. Originally, the specimen was identified as Macaca nemestrina (Southern Pigtailed Macaque). However, this is clearly a misidentification. UN 2619 is too small for an adult Macaca nemestrina, and its skull shape is more consistent with a colobine monkey. There is only one species of colobine with a short tail: Simias concolor (Pig-tailed Langur or Simakobu Monkey), endemic to the Mentawai Islands off the western coast of Sumatra, Indonesia and absent from the Sumatran mainland. Two subspecies are recognized (Groves 2001; BrandonJones et al. 2004; Zinner et al. 2013). Simias concolor is currently threatened by extinction (Whittaker 2006).

Simias concolor was described scientifically as recently as in 1903. The type specimen, the skin and skull of an adult male collected in 1902, is deposited in the United States National Museum in Washington, D. C. (Miller 1903). However, as the existence of UN 2619 shows, at least one specimen of Simias concolor was collected and deposited in a western natural history museum considerably earlier than 1902, and this specimen eventually ended up in the collections of the FMNH.

The second historically interesting specimen in FMNH is a flat skin with the collection number UN 1648. On the original label is written, by hand, in Finnish: "Papio sp., Nokia, Konola, 7.12. 1913". This indicates that the specimen came to the Museum from an unknown source in Finland, as the only geographical locality that "Nokia" may realistically refer to is the small Finnish town of Nokia.

The identification is incorrect; specimen UN 1648 is not a baboon as the facial region is too short and rounded for Papio. The animal is rather stocky, with relatively short limbs and tail (Figure 2). The head-body length is $530 \mathrm{~mm}$, and tail length $400 \mathrm{~mm}$. The dorsal colouration is greyish-brown, with a greenish tinge; this colouration extends to the limbs and tail. The ventral side is yellowish-white, as are the areas around the cheeks where the hairs are the longest. The palms of the hands and feet are black, the facial skin is lighter. The ears are relatively small and pointed. The ischial callosities are fused and modestly elongated; the genitalia are not preserved. The only primate species that matches specimen UN 1648 in size, shape, and colouration is Allenopithecus nigroviridis (Allen's Swamp Monkey) (Osman Hill 1964; Groves 2001; Kingdon 2007; Zinner et al. 2013). The morphology of the ischial callosities suggests that the specimen is a male (Osman Hill 1964). Allenopithecus nigroviridis is a cercopithecine native to the Congo Basin in Africa (Kingdon 2007). Two live individuals were held in captivity in Britain in the 1890s which were described as a new species, Cercopithecus nigroviridis, by Reginald Innes Pocock (1907). Later, Herbert Lang placed this monkey in the monotypic genus Allenopithecus, named after zoologist Joel Asaph Allen (Lang 1923).

At least one other Allenopithecus nigroviridis is known to have been imported to continental Europe at around the time of Pocock's original description. A young female was brought to the Lisbon Zoo, Portugal, from the French Congo (de Seabra 1909). However, there is no obvious explanation for how UN 1648 ended up in a small, land-locked town in what was at the time part of the Russian Empire. The only significant collection of live exotic animals within Finnish territory in 1913 was the Helsinki Zoo, and there are no records of anything identifiable as an Allen's Swamp Monkey having been kept there (Palmgren 1920). 
Therefore, UN 1648 probably belonged to a private owner before it was acquired by the FMNH. There are no signs of physical damage such as bullet holes in the skin, which suggests that it is not a hunting trophy. Also, a hunting trophy would more likely have been preserved as a mounted specimen, rather than as a flat skin. Thus, UN 1648 was probably imported alive to Finland. It may have been a pet, or, alternatively, it belonged to a circus or travelling menagerie and only happened to die while this establishment visited Nokia. The name "Konola" in the original label is perplexing. It does not match any current or known historical geographical name in the vicinity of Nokia. On the other hand, "Konola" is a fairly common Finnish surname, and the name could thus refer to the monkey's owner. Unfortunately, we have not found evidence of any person by that name who might have possessed a live African monkey in Nokia in 1913.

It may seem surprising that representatives of two such unique primate taxa as the Simakobu Monkey and Allen's Swamp Monkey were misidentified in the first place. However, as noted, at the respective points of time when these two specimens were added to the FMNH's collections, their existence had either become known only recently (in the case of Allenopithecus), or was not yet known at all (in the case of Simias) to the scientific community. Thus, the likely reason for their original misidentifications is that nobody considered the possibility that they would represent "new" species. These discoveries are a reminder of the significance of old zoological collections and that the possibility of finding unexpected taxa in unexpected places still exists.

\section{ACKNOWLEDGEMENTS}

We thank Mike Fowler for help with finding an important reference, and Colin Groves, Jussi Koivuniemi and an anonymous referee for comments. Our research was funded by the Anna och Signe von Bonsdorffs släktfond, the Waldemar von Frenckell Foundation, and the Ella and Georg Ehrnrooth Foundation.

\section{REFERENCES}

BRANDON-JONES, D., EUDEY, A. A., GEISSMANN, T., GROVES, C. P., MELNICK, D. J., MORALES, J. C., SHEKELLE, M. and STEWART, C.-B., 2004 Asian primate classification. International journal of primatology 25: 97-164.

DE SEABRA, A. F., 1909 Notes mammalogiques. IV. Cercopithecus. Bulletin de la Société Portugaise des Sciences Naturelles 2: 25-40.

GROVES, C. P., 2001 Primate taxonomy. Washington, D. C.

KINGDON, J., 2007 The Kingdon field guide to African mammals. Reprinted edition. London.

LANG, H., 1923 A new genus of African monkey, Allenopithecus. American Museum novitates 87: 1-5. MILLER, G. S., 1903 Seventy new Malayan mammals. Smithsonian miscellaneous collections 45: 1-73.

OSMAN HILL, W. C., 1964 The external anatomy of Allenopithecus. Proceedings of the Royal Society of Edinburgh, section B: biological sciences, 68: 302-326.

PALMGREN, R., 1920 Högholmens zoologiska trädgård åren 1888-1918. Acta Societatis pro Fauna et Flora Fennica 47: 1-240.

POCOCK, R. I., 1907 A monographic revision of the monkeys of the genus Cercopithecus. Proceedings of the Zoological Society of London 1907: 677-746. 
WHITTAKER, D. J., 2006 A conservation action plan for the Mentawai primates. Primate conservation 20: $95-105$.

ZINNER, D., FICKENSCHER, G. H. and ROOS, C., 2013 Family Cercopithecidae(Old World monkeys), pp 550-627 in MITTERMAIER, R. A., RYLANDS, A. B. and WILSON, D. E. (editors), Handbook of the mammals of the world. -Volume 3: Primates. Barcelona.

Received 10 February 2017. Accepted 1 March 2017.

HENRY PIHLSTRÖM ${ }^{\mathrm{A}}$ and TUULI LANKINEN ${ }^{\mathrm{B}}$

${ }^{A}$ (corresponding author) Physiology and Neuroscience, Department of Biosciences, P. O. Box 65 (Viikinkaari 1), FI00014, University of Helsinki, Finland. (henry.pihlstrom@helsinki.fi)

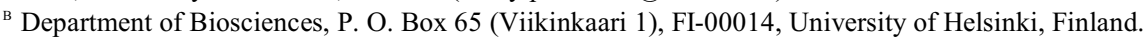
DOI: $10.3366 /$ anh. 2017.0000

\section{Elizabeth (Betsey) Ronalds (1788-1854): horticultural illustrator}

Hugh Ronalds's illustrated catalogue of apple cultivars, Pyrus malus Brentfordiensis (Ronalds 1831; Nissen 1951), was highly regarded especially for its numerous hand-coloured lithographs. The illustrations were created by his younger daughter, Elizabeth, who was known to relatives and friends as "Betsey". Little has been written about Betsey, but family papers now in the archives of Western University, London, Ontario, Canada, enable her life and nature to be described, and the scope, styles and purposes of her art to be explored, including its key role in promoting her family's nursery in Brentford (Ronalds 2017).

Betsey was born on 2 April 1788 at Brentford, to the west of London. The nursery established there by her grandfather had just passed to her father (see Ronalds 2017). Betsey was the third of Hugh and Elizabeth Ronalds's ten children and her only sister, Mary, was less than a year her senior. Cultivation of the mind was important in the family. Journals survive in which Hugh, Betsey and her siblings transcribed their favourite poetry and prose. The boys attended school in Uxbridge and the girls' education emphasized literature, music, art, French and needlework, as well as household management skills.

Betsey's rather cloistered upbringing in Brentford nonetheless limited her self-confidence and gave her a serious, conservative and concerned outlook on life. Personal integrity and betterment, modesty, and duty to society were her values, in line with her Nonconformist faith (Ronalds 2016). Like her sister and most of her brothers, she did not marry and they lived together in the family home. The expected role for Mary and Betsey was to keep house - they assisted their mother initially, and later cared for their widowed father and bachelor brothers. Although Mary carried the main domestic burden, it was a job that Betsey also enjoyed and she continued it up to her death on 5 May 1854.

Betsey and her siblings were able to travel widely for business and pleasure, through which she saw much of the United Kingdom and visited the continent a number of times. She commented at length in her journals on the art and sculpture she saw in different churches and museums, noting in particular the emotions it aroused in her as well as her perceptions of its quality. ${ }^{1}$ 